\title{
Pluralism in Crisis and Capabilities Approach: Martha Nussbaum's Philosophy from the Perspective of Political Aesthetics
}

\author{
Urszula Lisowska
}

The Institute of Philosophy, University of Wroclaw, Poland

Copyright $(2016$ by authors, all rights reserved. Authors agree that this article remains permanently open access under the terms of the Creative Commons Attribution License 4.0 International License

\begin{abstract}
The aim of the paper is to show the relevance of Martha Nussbaum's capabilities approach to the two types of the crisis in pluralist thinking which we are currently facing. The paper adopts the perspective of political aesthetics, in that it analyzes the political significance of the aesthetic motifs in Nussbaum's project. The conclusion is that Nussbaum's conception allows us to appreciate the central importance of education based on arts and humanities. It is argued that only with such background can the respect for pluralism be permanently secured.
\end{abstract}

Keywords Pluralism, Moral Education, Political Liberalism, Moral Psychology, Ethical Perception

\section{Introduction}

In one of her recent books, Not for Profit, Why Democracy Needs the Humanities? Martha Nussbaum offers a bold diagnosis of crisis. Published in 2010, the text begins with the mention of the economic crisis, only to immediately shift readers' attention to a different crisis, which, simultaneously, "goes largely unnoticed". This "silent crisis", as Nussbaum describes it, involves the crisis in education [1]. Schools and universities all over the world increasingly focus on sciences, which yield commensurable and practical results, thus neglecting (seemingly?) much more "intangible" humanities and arts. Obviously, these two tendencies do not come unrelated. Changes in education are at least partly motivated by economic anxiety, which sees scientific knowledge and technology as remedies for the current difficulties. From this perspective, humanities and arts may seem a bit of a luxury, which distracts our attention from the real issues at hand.

The current state of affairs on the global political scene adds a new dimension to Nussbaum's 2010 observations. The rise of the Islamic State, the related migration crisis in the Middle East and Europe, the terrorist attacks of
November 2015 - all these dramatic events have brought the normative foundations of the so-called Western democracies to their edge. As we struggle to remain committed to pluralism with its inclusiveness and, the same time, set reasonable limits to tolerance, the need to rethink our core political tenets seems more urgent than ever. Yet, all too often, the only response to this challenge is the resort to xenophobia. Instead of redefining the basis of pluralism, we yield to the rhetoric of "the clash of civilizations" and narrow the scope (and, inevitably, the content) of "Western" values.

What these two crises - the economic and the axiological - have in common is that they both promote simplified visions of the world. Just like the focus on purely economic factors impoverishes our understanding of development, the (apparent) conflict of values seems to undermine the project of multiculturalism. In other words, the crises represent two threats to pluralism - at the levels of, respectively, the constituents and the acceptable ideas of a good life. Such a common core suggests, in turn, that Nussbaum's re-valuation of arts and humanities as an alternative to economic reductionism is also relevant to the debate about the ideological diversity.

My objective will be to draft Nussbaum's argument in favor of this conclusion. According to Nussbaum, arts and humanities can convey the type of qualitative reasoning which is able to accommodate both the plurality of values and the diverse schemes of values. Therefore, their ongoing presence in the public life seems necessary (even if not sufficient), if the two respective forms of crises are to be combated. This observation is embedded in the context of Nussbaum's capabilities approach - a variety of a human-centered account of development (and justice), which Nussbaum combines with the philosophical ideas of political liberalism. It is this framework that constitutes the normative background of her project with its focus on the two dimensions of pluralism.

However, even though the paper will specifically concern the application of Nussbaum's theory, I will argue that the 
conclusions have more universal validity. This is because Nussbaum's focus on arts and humanities alerts us to the general relevance of education to the functioning of a society. She emphasizes that the right institutions and a prosperous economy are not enough for democratic values to gain stability. This broader perspective on the foundations of a democratic society is an insight that not only political philosophy, but social sciences in general can draw on.

\section{Methodology}

\section{Political Aesthetics as a Method of Interpretation}

Before I present the basic assumptions of Nussbaum's project, I would like to draft the method of interpretation adopted in the text. Namely, I suggest that we analyze Nussbaum's conception from the perspective of political aesthetics. As I understand it in the paper, the category of "political aesthetics" is precisely this - a way of reading rather than a distinct philosophical current. It traces possible overlaps between the political and the aesthetic in that it spells out the problems which emerge at the intersection of these two realms. My suggestion is that, when applied to Nussbaum's project, this method helps us capture how aesthetic motifs contribute to the achievement of her political objectives. In particular, I will argue that these elements play a crucial role in securing pluralism in both of the senses specified above. Nussbaum teaches us that we need to draw on the aesthetic, if we want to take into account the diversity of multifaceted ideas of a good life.

Understood, broadly, as a method, political aesthetics uses a wide range of traditions and concepts, such as Machiavelli's idea of virtu, the British empiricist notion of moral taste, Kant's critique of judgment and Hannah Arendt's interpretation thereof [2], as well as Elaine Scarry's recent inquiries about beauty and justice [3], to name just a few (and most pertinent). This is not to deny, however, that the concept of political aesthetics as such has also been thematized. In the most direct sense, the term can be associated with Crispin Sartwell, the author of the book Political Aesthetics [4]. A somewhat different, yet related approach has been developed by F. R. Ankersmit, who has come up with the idea of "aesthetic politics" [5]. As I have suggested, I will not limit myself to these projects. However, by explicitly taking up the problem of the "the political versus the aesthetic" relationship, Sartwell and Ankersmit help us determine two major points at which these domains intersect. Since both of them seem relevant to Nussbaum's project, it is worth sketching Sartwell's and Ankersmit's basic assumptions.

The former associates political aesthetics with the task of designing the public realm. For Sartwell the political is an arena where various claims, attitudes and doctrines meet. The aesthetic emerges as the source of organizational principles which offer a coherent vision of all these elements. Each political regime, argues Sartwell, has its own aesthetics, where the adopted ideal of beauty guides political practice in its attempts at integrating its constituents into one structure [6]. Thus, on Sartwell's understanding, political aesthetics begins with the diagnosis of the plurality inherent in the political sphere. This clearly resonates with Nussbaum's objectives - the deployment of aesthetics in political philosophy is a response to the perceived diversity of values and conceptions of what counts as valuable.

However, such responses can take various forms, expressed by the corresponding ideas of beauty. The very concept of the affinity between the political and the aesthetic was seriously discredited by Nazism (notably bemoaned by Walter Benjamin as the sign of "the aesthetization of politics"), which promoted the aesthetics of total unification. Therefore, interpreted as a design discipline, political aesthetics does not necessarily entail a pluralist and inclusive approach to socio-political issues [7]. In order to meet this objective, the search for the organizational principle has to be accompanied by a proper model of reasoning. Ankersmit's project highlights precisely this motif. The Dutch author suggests that political theory ought to involve a type of immediate apprehension which will enable us to grasp the complexity and the dynamics of political reality [8]. In this way, political judgment should resemble aesthetic judgment in its sensitivity to the plural character and uniqueness of its objects. Therefore, once again, we see the connection between politico-aesthetic inquires and Nussbaum's project. If Nussbaum's basic claim is that respect for pluralism calls for the revision of rationality, then Ankersmit suggests that the solution to this challenge can be found in the aesthetic realm.

Drawing on Sartwell's and Ankersmit's projects, then, we can define political aesthetics as the method which helps to construe such a model of reasoning that can capture and do justice to the diversity constitutive of the political realm. My aim will be to apply this approach to Nussbaum's theory. She begins with the diagnosis of plurality and reaches out to the aesthetic in order to draft an adequate model of rationality. Therefore, the politico-aesthetic perspective will enable me to present Nussbaum's response to the two crises of pluralist thinking - the economic and the normative.

\section{Argumentation}

\section{Capabilities-based Theory of Justice}

With these methodological comments in mind, we can move on to the overview of Nussbaum's basic philosophical assumptions. As I have mentioned, her commitment to the two dimensions of pluralism stems from her capabilities approach, which she presents as a variety of political liberalism. The former is a version of the theoretical framework which, originally formulated by Amartya Sen in the context of development economics [9], has come to be applied not only in many areas of the quality of life assessment (such as education, health, gender equality, 
human rights etc.), but also in political philosophy. Nussbaum represents the latter trend in that she uses the language of capabilities to formulate a minimal theory of justice.

Now, of course, as the range of the paradigm alone may suggest, the idea of capabilities (its application, scope, categorization etc.) has inspired many, often mutually polemical, interpretations and uses. The intricacies of the approach exceed the limits of this paper. What is of our interest, however, is the pluralist nature of the capabilities perspective. This is to do, firstly, with its anti-reductionist character. The capabilities approach focuses on the diversity of goods, refusing to limit itself to one criterion of development and/or justice (such as utility, preference satisfaction, GNP per capita etc.). In this way, it, secondly, introduces what Sen described as "the perspective of freedom" in that it attempts to account for the variety of things which people "have reason to value", i.e. which they (reasonably) choose to pursue. By focusing on capabilities alone and not on their actualization it does not push citizens into a specific level of functioning. At the same time, it differs from both the resource-based and purely legalist approaches, inasmuch as capabilities are defined as actual possibilities. In other words, the capabilities perspective asks how material goods, formal guarantees and other factors translate into real opportunities for functioning [10].

These, then, are the basic tenets of the capabilities approach. It takes three types of diversity into account - the plurality of the goods, of the ideas of the good and, characteristically, of the abilities to transform various resources into actual possibilities. Nussbaum uses these assumptions to develop a theory of justice. She argues that justice should be understood in terms of equal possibilities to pursue valuable activities. What is characteristic of her project is the insistence on the need to define a list of the priority capabilities. Her catalogue of ten "central human functional capabilities" provides an account of fundamental constitutional entitlements to which each citizens has an equal claim [11]. However, this solution is by no means uncontroversial. The problem of prioritization is among the most discussed within the capabilities approach, being also one of the major points of divergence between Nussbaum and Sen. Whereas it is generally agreed that there has to be some method of assessing the relative weight of capabilities (surely, the possibility to live a healthy life is more urgent than the ability to watch one's favorite TV series), it is often argued that a distinct list might prove too exclusive. In other words, although Nussbaum's conception clearly involves diverse values, it may seem less obvious that it is compatible with the variety of ideas of a good life. That is to say Nussbaum has to demonstrate that, in spite of its content-based character, her project is still liberal, i.e. respectful of each individual's right to choose her own scheme of goals.

\section{From Aristotle to Political Liberalism}

Nussbaum has always taken great care to defend her theory as liberal. The very interest in defining the lists reflects her Aristotelian background in that her catalogue is tailored to the Aristotelian account of the human condition (human beings as rational and sociable, but also animal and therefore needy), which constitutes the core of her conception [12]. Although this may not seem an obvious choice for a liberal, Nussbaum argues that, in fact, Aristotle's philosophy offers valuable insights from the perspective of pluralism. In her early writings on capabilities, she draws on Aristotle's model of ethical inquiry, presenting it as common sense and non-metaphysical. As she interprets it, the Aristotelian method of rationality involves the systematization of widely shared evaluative beliefs. Therefore, it can set an example for contemporary societies in that it shows us how to generate a consensus out of people's actual opinions rather than to impose a normative framework from without [13].

Nussbaum's more recent writings involve a shift in her attitude. She has moved from explicit Aristotelianism to the rhetoric of political liberalism, drawing primarily on John Rawls's elaboration of the approach. To put it very briefly, this variety of liberalism seeks to define the principles of justice without exclusively relying on any particular of many acceptable conceptions of the good life [14]. In Nussbaum's case, the intended transition into political liberalism is reflected by the introduction of the notion of equal human dignity. Instead of directly referring to a specific account of the human condition, she now uses this basic ethical category to define her catalogue of capabilities. The list is to represent the minimum conditions of a life in which, following Kant understands of dignity, each person is treated as an end in herself [15].

Nussbaum's claim to political liberalism is by no means unproblematic. As she herself declares, she has not abandoned her previous Aristotelian assumptions, but only reformulated them in a more pluralism-sensitive fashion [16]. It is not clear whether this rich background, committed to a specific account of a human being, could, in fact, be squared with the restrictions which political liberalism imposes [17]. Leaving these interpretational difficulties aside, however, we can say that Nussbaum's interest in the Rawlsian concept reflects her growing awareness of the pluralism of possible and acceptable worldviews. Moreover, having embraced the politico-liberal idiom, she has made respect for diversity one of the core values of her project. Respecting another person's dignity crucially includes recognizing her right to differ.

What these two stages - the Aristotelian and the politico-liberal - have in common is that they both connect regard for pluralism (of, both, the goods and the ideas of the good) with a specific model of reasoning, very broadly understood. In the first case, this is to do with the Aristotelian method of common-sense evaluative inquiry. As a variety of political liberalism, in turn, Nussbaum's project requires certain attitudes on the part of citizens. They have to be able to perceive the equal dignity of fellow human beings in order to treat them accordingly [18]. Such focus on reasoning judging and approaching each other in a proper way - 
reflects one constant feature of Nussbaum's conception. Namely, Nussbaum keeps underlining that, among central capabilities, two - affiliation and practical reason - are architectonic in that they organize and permeate the performance of all others [19]. Therefore, we could say that her capabilities theory is essentially a method - of thinking and of treating each other. It expresses an attitude, which manifests itself in a specific type of reasoning accompanied by mutual approach between individuals [20].

\section{Political Aesthetics Applied}

This brings us to the politico-aesthetic motifs in Nussbaum's conception. Using Sartwell's language, we could say that Nussbaum's capabilities approach offers a design of the political. Her theory functions as an organizing principle which arranges and assesses claims of citizens. However, more in Ankersmit's vein, the approach fulfills this politico-aesthetic task inasmuch as it is a method which crucially involves a model of reasoning. Such reservation is strictly connected with Nussbaum's regard for pluralism. That is to say, she construes her capabilities approach as an attitude which leads to the pluralist design of the political.

I suggest that it is in this context that the role of arts and humanities should be located. Nussbaum argues that, expressive as they are of qualitative, pluralism-sensitive reasoning, these disciplines are necessary for the cultivation of the capabilities approach understood as a type of an attitude. Therefore, according to the politico-aesthetic interpretation which I would like to offer, Nussbaum's theory can provide a design pattern of the political only when it is supported by education which draws on the aesthetic. Moreover, it seems that this educational task is twofold and corresponds with the two architectonic capabilities of affiliation and practical reason. That is to say, the aim of arts and humanities is to cultivate both a model of interpersonal relationships and a compatible method of reasoning. Such background allows us to see the capabilities approach as an overall attitude - the ability to respond to human dignity with proper judgment and treatment.

This is crucial from the perspective of pluralism. As I have suggested, Nussbaum presents respect for dignity as the main rationale for allowing for the variety of worldviews, which autonomous individuals may adopt [21]. Her rich understanding of the human condition enables Nussbaum, in turn, to provide a multifaceted account of the life compatible with human dignity. Therefore, it seems that the readiness to recognize human dignity - its various expressions and claims which it generates - is the foundation of pluralist thinking. If the capabilities approach is to design the political with regard to the diversity of goods and ideas of the good, it has to be supported by this attitude. The architectonic capabilities of affiliation and practical reason point to the two spheres of its cultivation.

\section{Reasonable Moral Psychology - Basic Ideas}

The focus on affiliation, to begin with, may seem to put Nussbaum's project at odds with the Kantian notion of dignity, the latter being usually associated with the idea of an atomized, independent subject. However, Nussbaum tries to combine these two traditions and encourages us to reconsider the Kantian idea from the Aristotelian perspective. Following Aristotle, she envisages human beings as inherently sociable, willing to engage in interpersonal relationships for their own sake. On this account, an individual sees the good of other people as a part of her own flourishing. Nussbaum's suggestion is that we should relocate the idea of dignity against such background. That is to say, for her respect for dignity is an attitude that cannot be acquired on the basis of abstract ethical principles alone. Rather, she argues, it should also be seen as an outgrowth of natural human sociability. The recognition of the rule has to be supported by the cultivation of our affiliating capabilities [22].

One of the major tasks of moral education, then, is to facilitate the development of mutual respect between individuals. Nussbaum takes up this issue in the recent addition to her project, i.e. a reasonable moral psychology. The very concept was originally formulated by Rawls in Political Liberalism and refers to the psychological elaboration of a given set of normative assumptions. In short, this type of inquiry seeks to explain how a theory of justice can be internalized by citizens. It is, thus, philosophical, not scientific - it starts from evaluative foundations and asks how, given what we can reasonably say about human psychology, these can be effectively exercised [23]. In Nussbaum's case this means that she uses the insights of contemporary psychological research to illuminate her account of human beings. Only with this background in mind, she argues, can we understand how individuals come to respect each other [24].

This is because for Nussbaum we only reach the mature and desirable form of sociability when we have come to terms with the fundamental tension inherent in our condition. Namely, as rational animals, we constantly waver between vulnerability and aspirations [25]. To live a dignified life means to strive against one's limitations, which, however, can never be fully overcome. This dialectic becomes most apparent in interpersonal relationships. On the one hand, sociability reflects our neediness - we reach out to others because we feel incomplete. On the other hand, though, the sense of dependency clashes with the sense of self-esteem. Aspiring as we are to live our ideas of the good life, we find this form of subjection difficult to accept. As a result, we become vulnerable to what Kant described as radical evil the tendency to treat others as mere means to one's own end. That is to say, we attempt to control the persons that we need so that we have the illusion of not being dependent on them. In this way, the refusal to accept what it means for me to live a life compatible with human dignity, leads me to question the dignity of others [26].

\section{Narcissism, Anthropodenial, Emotions}

The basic question of Nussbaum's moral psychology, then, is how these exploitative relationships can be avoided and a 
more balanced type of interaction achieved instead. Nussbaum describes the desirable attitude as "mature interdependence", i.e. the state in which persons both recognize each other's separateness and acknowledge their mutual dependencies [27]. The term is a paraphrase of W.R.D. Fairbairn's ideas, whose name, along with the above description, points to the direction of Nussbaum's psychological considerations. Namely, Fairbairn represents the object relations perspective in psychoanalysis, which is one of the major inspirations for Nussbaum. Her objective is to trace "radical evil" back to fundamental human anxieties, which become most apparent in early childhood. It is also here, she argues, that we can find the resources to combat these dangerous tendencies.

Drawing on the works of such object-relations theorists as Fairbairn, Daniel Stern, John Bowlby and, most importantly, Donald W. Winnicott, Nussbaum analyses the formative influence of infantile helplessness on our future moral attitudes [28]. The object relations perspective takes early childhood dependency as its starting point and moves on to show how a mature self gradually develops out of the initial state of immersion in the surroundings. On this account, an individual acquires the sense of her separateness only through and in the context of meaningful relationships, in particular - interpersonal relationships. Thus, the object relations theory captures the very tension between independence and the need to relate that Nussbaum places at the core of her conception [29].

With the help of this perspective, she links the difficulties in balancing these two claims to narcissism. We crave for the original - yet illusionary - omnipotence, from the times when the world seemed to dote on us. The refusal to accept one's own limits and the separateness of others, Nussbaum argues, is the reflection of this infantile egocentric longing [30]. To this she adds a category from a different tradition, i.e. Frans de Waal's idea of anthropodenial. The Dutch primatologist has used the term to refer to "the tendency of humans to refuse to acknowledge their animality and kinship with other animals" [31]. What we reject when we deny autonomy to others, she suggests, is ultimately the sense of our own limitations rooted in human bodiliness.

We can thus see that contemporary research helps Nussbaum develop her philosophical assumptions. In her moral psychology, she uses the categories of narcissism and anthopodenial to explain how the problematic relationship of humans to their weaknesses can lead to what she describes as radical evil. She then argues that, in order to confront these difficulties, we need to focus on one sphere of human experience in particular, namely - on emotions. Nussbaum has extensively written on this topic, drawing on both philosophical and psychological sources. In short, her theory is a combination of Stoicism and cognitive psychology in that it defines emotions as evaluative judgments which assess reality from the perspective of one's idea of the good life (eudaimonia). This is not to say that they amount to purely instrumental reasoning; quite the opposite, the objects of emotions are seen as inherently valuable and, therefore, be crucial to the subject's well-being. This implies that in most cases emotions are directed at external goods and express the sense of dependency and imperfect control [32]. For this very reason they can often provide an outlet for narcissistic and anthropo-denying tendencies. Nussbaum associates this risk with such emotions as disgust, shame and envy, all of which can take the form of projecting one's own insecurities onto others [33]. At the same time, however, precisely because of their relation to the experienced dependency, emotions may also represent a more mature approach to human neediness. When properly cultivated, they express commitments to "external goods" - especially to other people - which follow the pattern of mature interdependence. As we shall see, it is one of the levels at which arts and the aesthetic at in general come - literally - into play.

\section{From Childhood Play to the World of Art}

Like in her theory of emotions in general, when speaking about their cultivation, Nussbaum combines psychological research with philosophical assumptions. In order to locate this educational task within the process of the development of the self, she draws primarily on the work of Donald W. Winnicott. An object-relations theorist, Winnicott offered original insights into ego maturation. Namely, he argued that successful object-relating and the accompanying moral development essentially involve the transformation of our innate creative impulse. For Winnicott, narcissism expresses this basic capacity, representing as yet unabated desire to create one's own world. In order to curb the claim to omnipotence, human creativity has to be redirected so that it can fulfil itself by means of contributing to the external world. The culminating point in this process is the so-called ambivalence crisis, which takes place when a child discovers the negative influence of her frustration-driven anger at the environment. In a response to that, she gradually develops the capacity for concern in an attempt to compensate for her destructive behavior [34].

Ego maturation, then, is reflected in the corresponding transformation of emotions, i.e. the move from self-centered sentiments towards active other-directed care. To grow up, we have to renounce the illusionary sense of unlimited agency, while retaining and reconfiguring our inborn creativity. This, however, means that maturation is in fact a very subtle process of disillusionment, a constant push and pull between one's own initiative and "the terms and conditions" dictated by reality. What allows us to engage in this type of benign and never fully complete disenchantment is, Winnicott argues, the experience of play. According to Winnicott, play constitutes "an intermediate area" between fancy and reality, between internal and external world. It is "a potential space" which can be creatively shaped by individuals but, at the same time, possesses a degree of independence. In this sense play enables us to "negotiate" with reality so as to determine the scope of our agency. What is more, play is not only a childhood experience. Quite the opposite, Winnicott underlines that it lives on in the adult forms of creativity - cultural, religious, scientific and, most 
importantly, artistic [35].

\section{Wonder and Dignity}

Therefore, we could say that Winnicott offers a psychological deduction of the educational value of art. Nussbaum adopts this framework and, in accordance with the general character of her moral psychology, provides it with philosophical underpinnings [36]. Most importantly, she connects Winnicott's idea of human creativity to the philosophical category of wonder. She argues that human beings have an innate capacity for this special emotion, which is "as non-eudaimonistic as an emotion can be" [37]. By this, Nussbaum means that when we wonder at something (somebody) we perceive its (her) inherent value irrespectively of our ideas of the good life. Therefore, wonder is related to the creative impulse in that it inspires us to venture outside our usual way of thinking and approach the world with curiosity and attention [38]. Play and arts, Nussbaum argues, draw on and strengthen this emotion. They create a safe environment, where we can open ourselves to the surprises of the unpredictable world. At the same time, play and arts also empower their participants to imaginative interpretation or creation. In this way, they help us develop the capacity for wonder understood as the ability to, both, give in and actively respond to the uncontrollable [39].

However, the role of play and arts is not purely practical. In that it "responds to the pull of the object" wonder encourages us to see it as worthy of concern simply by virtue of its delightfulness. Moreover, given that other emotions involve the recognition of the immanent worth of their objects, wonder appears to be their constitutive element [40]. Therefore, we can follow Benedik-Keymer's revealing interpretation and assume that wonder thus understood should be treated as the emotion responsible for the perception of dignity. It is through this emotion that we learn to see the autonomy of another person not as a threat to one's own well-being, but as the source of inherent worth [41]. This means, in turn, that the appreciation of dignity is very much like aesthetic contemplation. When we experience a work of art, we likewise marvel at its non-instrumental value. In this sense, beauty and dignity converge at least at the phenomenological level [42]. They are both grasped in the same process of wondering at the autonomous worth of their "carriers". To treat another person as an end, is to treat her as beautiful, i.e. "useless", and not subjected to one's own purposes.

Therefore, Nussbaum's moral psychology suggests the crucial political importance of the aesthetic. Wonder and the world of play and arts emerge as the necessary conditions of cultivating the desirable type of sociability. When we appeal to the capacity for wonder, we encourage individuals to approach the autonomy of other people (as the source and the mark of their limitations) with curiosity and respect, rather than with dread and hostility. In this way, wonder has a "soothing" influence on narcissistic and anthropo-denying tendencies. Play and arts support this capacity and enable us to experience it in conjunction with imaginative creativity.

As a result, when founded on genuine wonder, aesthetic experience facilitates respect for pluralism. When we come to appreciate the autonomy of other individuals, we are also ready to accept their right to differ. However, this attitude has to be completed by an adequate way of thinking - the ability to recognize various expressions and claims of dignity in our judgments. In other words, the architectonic capability of affiliation needs to be cultivated in conjunction with practical reason. Therefore, before I move on to the examples of the educational use of arts, I would like to sketch Nussbaum's model of practical rationality.

\section{Practical Rationality}

It has to be underlined that the interest in the model of rationality belongs to the earlier stage of Nussbaum's project. Her ethical texts were published more or less simultaneously with the first version of the capabilities approach and offer a complement to the Aristotelian method of evaluative inquiry. However, given the problematic nature of Nussbaum's later transition to political liberalism, I believe that there is much more continuity in her position than she is sometimes willing to admit. In particular, I will argue that her model of ethics is compatible with her reasonable moral psychology, the link between them being their likewise aesthetic character.

To put it briefly, Nussbaum describes her Aristotle-inspired model of ethics as non-scientific. As opposed to such traditions as utilitarianism and Kantianism, it does not seek unquestionable ethical knowledge. Instead, it calls for the sensitive perception of the unpredictable and messy world of acting [43]. In order to formulate a proper ethical judgment, Nussbaum argues, we need to perceive the situation at hand in its specificity. This means that we have to take into account various non-commensurate goods involved in the context, seeing it both as an example of a rule and the unique case. To this end, we should employ not only the capacity for analytical thinking, but also emotions and imagination [44].

Clearly, this model of rationality is sensitive to the plurality of items which make up a good life. Ethical perception represents qualitative thinking, which captures the subtleties of our evaluative beliefs. With its focus on non-commensurability and particularity, it stands in direct opposition to reductionist accounts of well-being. In this sense, it is compatible with the capabilities approach understood as an alternative to one-dimensional conceptions of development, such as those based on purely economic or utilitarian criteria. What may seem more problematic is whether ethical perception can take into account the plurality of internally diversified ideas of the good as well. For, given its Aristotelian background, it may seem that the method corresponds with only one of such conceptions.

The aesthetic character of ethical perception seems to alleviate precisely this worry. The very term "perception" has aesthetic connotations, inasmuch as it stems from the Greek notion aisthesis. This background resonates in Nussbaum's suggestion that ethical judgment resembles both 
the experience of art and its creation. Firstly, "moral attention" is in fact the same type of attention that a work of art elicits. In both cases, we are humble and responsive to the object; we let ourselves be surprised and refrain from imposing our prior expectations on the perceived phenomena. Therefore, if we connect this assumption to Nussbaum's moral psychology, we can say that perception represents the attitude of wonder at the level of ethical judgment. And inasmuch as wonder responds to dignity, perception emerges as the type of reasoning respectful of this value. To follow this method is to formulate judgments with regard to the dignity of involved persons. This, in turn, means that perception is sensitive to the plurality of perspectives which these individuals represent. Secondly, Nussbaum observes that this method is itself a form of artistic creativity. It could be compared to novel writing in that it likewise consists in composing insightful and apt interpretations of reality. It also resembles theatrical or musical improvisation, because it rests on the ability to creatively apply the rules in ever changing circumstances. In either case, perception is a creative response to the dynamics of the world of acting [45].

If we put these two aspects together, we will see that perception involves the same combination of activity and passivity at which the cultivation of emotions aims. Nussbaum's model of rationality and moral psychology, then, are at least isomorphic. But, although they belong to different stages of Nussbaum's project, they are in fact much more tightly connected - to the extent of their mutual complementarity. On the one hand, the education of emotions helps us recognize the dignity of other people. Supplied with this background, perception emerges as the method of reasoning sensitive to the diversity of individual perspectives. On the other hand, perception brings clarity to our responses, including emotions. When we follow this pattern, we learn to make fine distinctions and respect the subtleties of particular ideas of the good life [46]. Therefore, it seems that if we want to guarantee both the plurality of the goods and of the conceptions of the good, we should consider Nussbaum's model of ethics and moral psychology in conjunction [47].

\section{Discussion}

\section{Political Aesthetics and the Two Crises}

The objective of the preceding paragraphs was to apply the point of view of political-aesthetics to Nussbaum's project. As I understand it, this perspective analyzes the relevance of the aesthetic to the pluralism-sensitive type of reasoning in the political realm. I have argued that Nussbaum's capabilities approach can be interpreted as a method of such reasoning, which involves both mutual attitudes of citizens and a model of ethical judgment. Focusing on Nussbaum's moral psychology and account of rationality (which correspond to the architectonic capabilities of affiliation and practical reason, respectively), I have pointed to the aesthetic motifs in Nussbaum's conception.

How does, then, this politico-aesthetic interpretation refer to the two crises mentioned at the beginning? We need to ask, firstly, in what way the moral education of emotions and practical rationality can contribute to the combating of these two dangerous tendencies - the weakening trust in liberal democracy and the reductionist understanding of human well-being. Is it not naïve to resort to education, when confronted with such grave contemporary processes? To respond to this challenge, we have to accurately define the scope of the following observations. Obviously, the two crises have complex roots - economic, political, historical and other - which cannot be tackled simply by cultivating proper attitudes of citizens. However, to the extent that I am interested in the changes in the human mindset prompted by such processes as migration or financial crisis, I also see the role of education in this department. Namely, Nussbaum's project allows us to argue that moral education is necessary, if all these problems are to be solved with humanity in mind, i.e. while keeping human well-being in focus.

Secondly, we have to locate arts and humanities within the educational task thus understood. I have presented a general argument in favor of the moral relevance of these disciplines, when speaking about ego development. Nussbaum has given a lot of, often very diverse, examples of the educational use of arts and humanities. I suggest that, for the sake of clarification, these practical implications could be divided into three categories, depending on the challenge which they answer. For we can assume that, of the two crises, each roughly corresponds to one of the main areas of education.

The demise of liberal thinking, to start with, reflects the crisis of certain ethos, the want of proper civic attitudes. When considered from the perspective of Nussbaum's moral psychology, the refusal to accept the plurality of views could be linked to the narcissistic fear of the uncontrollable. Therefore, if art is to contribute to the combating of this tendency, it should foster a different type of relationships, based on mutual trust and respect. This, it seems, can be achieved through such artistic activities that encourage real-life encounters. When individuals meet in a safe, art-mediated environment, they can approach each other with wonder, rather than with suspicion. Many examples which Nussbaum presented in her most recent publication, Political Emotions, point precisely in this direction. She mentions public monuments ("The Bean" in Chicago or Vietnam Veterans Memorial in Washington), parks (Central Park in New York) and urban revitalization projects, arguing that such initiatives facilitate better, more inclusive interactions between citizens [48]. In general, urban design the creation of actual meeting spaces - seems particularly important in the process of cultivating pluralism-sensitive attitudes of citizens [49].

In order to counteract the reductionist thinking about human well-being (prompted by the economic crisis), we need, in turn, to cultivate a subtler model of rationality, such as ethical perception. Here the key role belongs to literature, and especially to novels. Nussbaum's reflections about the 
affinity between ethics and novels go very deep, and her idea of perception owes as much to Henry James as it does to Aristotle [50]. Her basic assumption is that the form of a novel allows for a very apt representation of ethical perception, which, moreover, is exercised while reading. A literary work, as a work of art, is both an expression and object of perception. When we read a novel, we learn the examples of fine distinction-making, and at the same time perform the very process with regard to the text at hand. Most importantly, the reader's perspective facilitates both emotional and imaginative immersion, and critical distance to the presented world and one's own responses. In this way, such an aesthetic experience is an exercise in qualitative and reflective thinking [51].

Finally, Nussbaum has written extensively on the educational system in democratic societies, showing how the two aspects described above could be combined. For, as I have suggested, mutual attitudes and practical rationality should be cultivated in conjunction. To this end, Nussbaum argues, the ongoing presence of various types of arts and humanities in curricula (from primary schools to universities) should be secured. Citing Rabindranath Tagore's theory of education, she underlines the role of performing arts, such as theatre and dance, in school education [52]. She also stresses the importance of novel reading for various disciplines, including the interpretation and application of law [53]. Most importantly, Nussbaum emphasizes that all these activities should be exercised in the spirit of what she calls "Socratic pedagogy". That is to say, aesthetic experiences should encourage us to engage in a respectful dialogue with each other, so as to analyze and better understand one another's, but also - our own beliefs [54]. This type of education is necessary, if we want to cultivate reasoning sensitive to the plurality of, both, goods and ideas of the good.

\section{Arts and Social Justice}

Based on the above model of education, we can point to the relevance of arts and humanities not only to pluralism as such, but also to the pluralist conception of justice, as Nussbaum presents it in her capabilities approach. Both aspects of moral education are pertinent to the application of this model.

First, we could say that moral psychology deals with the very foundations of just treatment. Nussbaum uses psychological insights to explain how we come to see ourselves and each other as subjects of claims. She thus suggests that citizens will not treat one another justly unless they acknowledge the specificity of the human condition, with its rationality and animality. In particular, she argues that the promotion of capabilities approach requires the cultivation of the emotion of compassion, i.e. the concerned response to undeserved and serious suffering of fellow human beings. Nussbaum's capabilities catalogue can be seen as the list of good grounds for incorporating compassion into public reasoning. In this sense, justice requires compassion; its objectives can be more easily met if citizens are ready to feel this emotion [55].
Secondly, Nussbaum's model of practical rationality supplements her capabilities approach with a possible method of its application. As I have suggested, ethical perception corresponds with the capabilities-based account of well-being. In order to realize this nuanced and qualitative conception of justice, we need to reason in a likewise subtle and multifaceted manner. Therefore, Nussbaum presents her method as a model of not only private, but also public rationality to be used by political leaders [56].

\section{Confronting Possible Objections}

Although the politico-aesthetic perspective offers a novel interpretative angle, many of the themes from Nussbaum's project analyzed in the paper have been discussed in literature. In particular, as I have mentioned, her claim to political liberalism has been widely commented. Although Nussbaum's stance has found some advocates [57], its politico-liberal character is usually questioned [58]. Interestingly, Okin suggested that Nussbaum's project does not comply with political liberalism precisely because of its focus on education [59]. In my interpretation, I have followed a middle road represented by such writers as Comim and Gasper [60]. That is to say, I have analyzed Nussbaum's work in its entirety, bringing together elements from before and after her declared transition to political liberalism. Having reviewed Nussbaum's model of education, we can now say that, politico-liberal or not, her conception meets the basic objective of this variety of liberalism. She manages to build respect for the pluralism of the ideas of the good (as well as - of the goods) into her project.

Such a comprehensive account of Nussbaum's project allows us also to respond to another type of charges. Namely, Nussbaum's idea of ethically engaged literary criticism has often been criticized as oversimplified and narrow. For example, Vasterling has accused Nussbaum of "methodological solipsism", arguing that the act of reading solitary as it is - cannot have such moral significance as Nussbaum ascribes to it. Encounters with real people are very much different to encounters with literary characters and the latter cannot serve as "the matrix" for the former [61]. Eaglestone, in turn, criticized Nussbaum's naïve representational understanding of literature. According to him, Nussbaum does not take into account the autonomous textual nature of literary works [62]. If, however, we locate Nussbaum's reflections on literature in the broader context of her model of education, these charges can be at least alleviated. Literature reading is now seen as the continuation and clarification of real-life experiences. The perception of novels draws on the attitudes cultivated in the extra-literary world and itself helps us improve our understanding of reality.

\section{Conclusions}

My opening hypothesis was that, when applied to 
Nussbaum's capabilities approach, the politico-aesthetic perspective enables us to capture its relevance to the two crises in the pluralist thinking - the crisis pertaining to the acceptable ideas of a good life and the increasingly reductionist understanding of the constituents of $a$ good life. I have traced overlaps between Nussbaum's political assumptions and aesthetic motifs, showing that the type of reasoning compatible with her pluralist ideas strongly relies on the aesthetic experience. This has led me to conclude that moral education based on the affinity between the political and the aesthetic plays an important role in the counteracting of the two dangerous tendencies. In the most direct sense, arts and humanities should be extensively employed with a view to cultivating citizens' attitudes.

I have specifically focused on Nussbaum's capabilities approach. We have seen that her assumptions both enable her to define a model of reasoning and require its cultivation for their application. However, as I have suggested at the beginning, the conclusions presented in the paper seem to be more universal in scope. Namely, Nussbaum alerts us that the foundations of democracy are indeed very fragile. Whether we adopt an Aristotelian conception of the human being whose well-being is defined in terms of capabilities, opt for the Rawlsian language of primary goods compatible with his Kantian model of the person, or choose yet another solution, we cannot rest content with defining proper abstract principles and securing right institutions. Rather, as Nussbaum's project allows us to conclude, societies committed to the plurality of (often internally diversified) ideas of the good have to care for the education of their citizens. The same obtains with respect to the broader question of social justice in pluralist societies. Just institutions have to be supplemented with proper attitudes, which do not replicate themselves automatically. On the contrary, they have to be consciously and carefully nurtured. Such education is a necessary, even if not sufficient, foundation of a just, pluralist society.

\section{Acknowledgments}

The project has been funded by the National Science Centre (Poland), based on the decision number DEC-2013/09/N/HS1/02864.

I have addressed related issues in an earlier paper (Lisowska U. The Arts and the Promotion of Capabilities in Times of Crisis. Martha Nussbaum's Philosophy from the Perspective of Political Aesthetics. Studia Philosophica Wratislaviensia. 2014; English Edition: 65-88). The current article presents a revised and developed approach to the politico-aesthetic motifs in Nussbaum's philosophy.

\section{REFERENCES}

[1] Nussbaum M. C. Not for Profit. Why Democracy Needs the
Humanities. Princeton University Press: Princeton and Oxford; 2010. p. 1-11.

[2] Arendt H. Lectures on Kant's Political Philosophy. University of Chicago Press: Chicago; 1982.

[3] Scarry E. On Beauty and Being Just. The Tanner Lectures on Human Values delivered at Yale University; March 25 and 26 1998.

[4] Sartwell C. Political Aesthetics. Cornell University Press: Ithaca and London; 2010.

[5] Ankersmit F. R. Aesthetic Politics. Political Philosophy beyond Fact and Value. Stanford University Press: Stanford; 1996.

[6] Sartwell C. Political Aesthetics. Cornell University Press: Ithaca and London; 2010. p. 8-11. Rawlsian model of justice as fairness - the latter term being more or less synonymous with both "justice" and "beauty" (E. Scarry, On Beauty and Being Just. The Tanner Lectures on Human Values delivered at Yale University; March 25 and 26 1998. p. 62-75) may be seen as a pattern of designing political reality in accordance with the aesthetic ideal of plurality and subtlety (even if Rawls hardly ever uses explicitly aesthetic language).

[7] Sartwell C. Political Aesthetics. Cornell University Press: Ithaca and London; 2010. p. 15-47.

[8] Ankersmit F. R. Aesthetic Politics. Political Philosophy beyond Fact and Value. Stanford University Press: Stanford; 1996. p. 14-15.

[9] Sen A. Poverty and Famines. An Essay on Entitlement and Deprivation. Clarendon Press: Oxford; 1981.

[10] On the basic assumptions of the capabilities approach, see, for example, Sen A. Inequality Re-examined. Russell Sage Foundation: New York; Clarendon Press: Oxford; 1992.

[11] The list includes the following items: life, bodily health, bodily integrity, senses, imagination, and thought, emotions, practical reason (the ability to define and pursue one's idea of the good), affiliation (this includes the ability to form relationships with other people and protection from discrimination), relation to other species, play, control over one's political and material environment (see, for example, Nussbaum M.C. Women and Human Development. The Capabilities Approach. Cambridge University Press: New York; 2000. p. 78-80).

[12] Nussbaum realized that Aristotle's category of "dynamic" and the related functional account of the good human life can be developed in the language of capabilities. This framework corresponds with Aristotle's insistence on human animality and the related dependency on external circumstances. Drawing on Aristotle, Nussbaum introduced three types of capabilities, which reflect various types of dependency: basic capabilities (our innate equipment), internal capabilities (mature states of individuals developed with the help of external support, such as nourishment, education etc.) and combined (internal capabilities coupled with external conditions necessary for their actual performance). The list includes the last type of capabilities (Nussbaum M. Nature, Function and Capability. WIDER Working Papers; December 1987).

[13] See, for example, Nussbaum M. C. Human Functioning and Social Justice: In Defence of Aristotelian Essentialism. Political Theory. 1992; 20 (2): 202-246. Nussbaum M. C. Aristotle on Human Nature and the Foundations of Ethics. In: 
Altham J.E.J. and Harrison R., editors. World, Mind, and Ethics: Essays on the Ethical Philosophy of Bernard Williams. Cambridge University Press: Cambridge; 1995. p. 86-131.

[14] Apart from Rawls, another major representative of this approach is Charles Larmore. Although these two authors worked independently and in slightly different context, they reached similar conclusions. See: Rawls J. Political Liberalism. Columbia University Press: New York; 1993, 1996. Larmore Ch. The Morals of Modernity. Cambridge University Press: Cambridge; 1996. Larmore Ch. Patterns of Moral Complexity. Cambridge University Press: Cambridge; 1997.

[15] See, for example, Nussbaum M. C. Frontiers of Justice. Disability, Nationality, Species Membership. The Belknap Press of Harvard University Press: Cambridge, Massachusetts, London, England; 2007, p. 159-164. Nussbaum M. C. Creating Capabilities. The Human Development Approach. The Belknap Press of Harvard University Press: Cambridge, Massachusetts, London, England; 2011. p. 17-45.

[16] Nussbaum M. C. Political Liberalism and Respect. Sats Nordic Journal of Philosophy. 2003; 4(2): 25-44.

[17] Nussbaum's allegiance to political liberalism has been extensively commented and often criticized. There seem to be two main points of divergence between these two projects. Firstly, political liberalism concentrates on citizenship. Rawls's "political conception of the person" pertains to individuals in their role of citizens. Although Nussbaum also presents her Aristotelian model as an account of citizenship, it is still rooted in her broader understanding of the human condition. The idea of human dignity as the standard for the relationships between citizens anchors Nussbaum's project in this richer background. Secondly, it has been argued that Nussbaum's project and the capabilities approach in general are not compatible with political liberalism because of their focus on the good (or, to speak more generally, on the results). Political liberalism, on the other hand (especially in Rawls's case), has strong connection to the social contract model with its prioritization of the right. (see Alexander J. M. Social Justice and Nussbaum's Conception of the Person. In: Comim F., Nussbaum M.C., editors. Capabilities, Gender, Equality. Towards Fundamental Entitlements. Cambridge University Press: Cambridge; 2014. p. 414-436). My suggestion is that because of and thanks to - her Aristotelian commitments, Nussbaum does not meet all politico-liberal requirements. However, this is does not mean that she fails to achieve the main objective of this approach, i.e. to account for the fact of the reasonable pluralism. Quite the opposite and, to an important extent, because of her richer assumptions, she builds the guarantees for pluralism into her conception. Crucially, this depends on her account of reasoning.

[18] Nussbaum M. C. Frontiers of Justice. Disability, Nationality, Species Membership. The Belknap Press of Harvard University Press: Cambridge, Massachusetts, London, England; 2007, p. 408-415.

[19] Nussbaum M. C. Creating Capabilities. The Human Development Approach. The Belknap Press of Harvard University Press: Cambridge, Massachusetts, London, England; 2011. p. 39-40.

[20] Gasper D. Logos, pathos and ethos in Marta C. Nussbaum's capabilities approach to human development. In: Comim F., Nussbaum M.C., editors. Capabilities, Gender, Equality. Towards Fundamental Entitlements. Cambridge University Press: Cambridge; 2014. p. 96-130.
[21] Nussbaum M. C. Political Liberalism and Respect. Sats Nordic Journal of Philosophy. 2003; 4(2): 25-44.

[22] Nussbaum M. C. Frontiers of Justice. Disability, Nationality, Species Membership. The Belknap Press of Harvard University Press: Cambridge, Massachusetts, London, England; 2007. p. 156-160. Nussbaum M. C. Political Emotions. Why Love Matters for Justice. The Belknap Press of Harvard University Press Cambridge, Massachusetts, London, England; 2013. p. 10-11.

[23] Rawls J. Political Liberalism. Columbia University Press: New York; 1993, 1996. p. 86-88.

[24] Nussbaum M. C. Political Emotions. Why Love Matters for Justice. The Belknap Press of Harvard University Press Cambridge, Massachusetts, London, England; 2013. p. 8-16.

[25] Ibid., p. 118-124.

[26] Ibid., p. 162-168. Kant I. Religion within the Bounds of Sheer Reason. Transl. Philip McPherson Rudisill. Online available: $\mathrm{http}: / /$ kantwesley.com/Kant/RationalReligion.pdf.

[27] Nussbaum M.C. Upheavals of Thought. The Intelligence of Emotions. Cambridge University Press: New York; 2008. p. 224.

[28] Ibid., 180.

[29] Ibid., 174-206.

[30] Ibid., 181-190. Nussbaum M. C. Political Emotions. Why Love Matters for Justice. The Belknap Press of Harvard University Press Cambridge, Massachusetts, London, England; 2013. p. 168-174.

[31] Ibid., p. 159.

[32] Nussbaum M.C. Upheavals of Thought. The Intelligence of Emotions. Cambridge University Press: New York; 2008. p. 19-88.

[33] Ibid., 190-206. See also, Nussbaum M.C. Hiding from the Humanity. Disgust, Shame and the Law. Princeton University Press: Princeton and Oxford; 2004.

[34] Winnicott D. W. The Capacity for Concern. In: Winnicott D. W. The Maturational Process and the Facilitating Environment: Studies in the Theory of Emotional Development. The Hogarth Press and the Institute of Psycho-Analysis: London; 1965. p. 73-82.

[35] Winnicott D. W. Playing and Reality. Routledge Classics: London and New York; 2005.

[36] Nussbaum M.C. Upheavals of Thought. The Intelligence of Emotions. Cambridge University Press: New York; 2008. p. 206-224. Nussbaum M. C. Political Emotions. Why Love Matters for Justice. The Belknap Press of Harvard University Press Cambridge, Massachusetts, London, England; 2013. p. 177-182.

[37] Nussbaum M.C. Upheavals of Thought. The Intelligence of Emotions. Cambridge University Press: New York; 2008. p. 55 .

[38] Ibid., p. 55-56, 189-190.

[39] Nussbaum M. C. Not for Profit. Why Democracy Needs the Humanities. Princeton University Press: Princeton and Oxford; 2010. p. 95-120. 
[40] Nussbaum M.C. Upheavals of Thought. The Intelligence of Emotions. Cambridge University Press: New York; 2008. p. $55-56$.

[41] Bendik-Keymer J. From humans to all life: Nussbaum's transformation of dignity. In: Comim F., Nussbaum M.C., editors. Capabilities, Gender, Equality. Towards Fundamental Entitlements. Cambridge University Press: Cambridge; 2014. p. 175-192.

[42] See also: Scarry E. On Beauty and Being Just. The Tanner Lectures on Human Values delivered at Yale University; March 25 and 26 1998.46-54.

[43] Nussbaum borrows the term "perception" from Aristotle, who observed in Nichomean Ethics that "the discernment rests with perception" (see: Nussbaum M. C. The Discernment of Perception: An Aristotelian Conception of Private and Public Rationality. In: Nussbaum M. C. Love's Knowledge. Essays on Philosophy and Literature. Oxford University Press: New York, Oxford; 1992. p. 54-105).

[44] Nussbaum summarizes the Aristotelian model of rationality by means of four main assumptions: non-commensurability of values, the priority of the particular, the rationality of emotions and ethical relevance of the uncontrollable events (Nussbaum M.C. Introduction: Form and Content, Philosophy and Literature. In: Nussbaum M. C. Love's Knowledge. Essays on Philosophy and Literature. Oxford University Press: New York, Oxford; 1992. p. 35-44.).

[45] Nussbaum M.C. »Finely Aware and Richly Responsible«: Literature and the Moral Imagination. In: Nussbaum M. C. Love's Knowledge. Essays on Philosophy and Literature. Oxford University Press: New York, Oxford; 1992. p. 148-167.

[46] Compare: ibid., 161-164.

[47] It is interesting to put for this model in the context of Kant's judgment of taste, and especially - Hannah Arendt's interpretation thereof. According to Kant, taste, i.e. the judgment of beauty, consists in recognizing the non-instrumental value of an object without the mediation of any prior general concept (Kant I. The Critique of Judgment. Transl. J.H. Bernard, Online available: Online Library of Liberty, http://oll.libertyfund.org/). However, as Arendt pointed in her Lectures..., the non-conceptual character means that taste is a type of sensus communis, the form of reasoning which requires a shared ethos. This constant exchange between the openness to novelty and the sense of belonging led Arendt to suggest that taste might be located at the core of political philosophy (Arendt H. Lectures on Kant's Political Philosophy. University of Chicago Press: Chicago; 1982.). It seems that, when taken together, Nussbaum's model of ethics and moral psychology constitutes a similar model. The cultivation of emotions caters for the ethos and perception introduces clarity and criticism.

[48] Nussbaum M. C. Political Emotions. Why Love Matters for Justice. The Belknap Press of Harvard University Press Cambridge, Massachusetts, London, England; 2013. p.284-288, 299-301, 333-338, 356-359.

[49] Here we can recall Sartwell's idea of political aesthetics as the designing of the plurality inherent in the political realm. We could say that the public space allows for a literal visualization of such diversity.
[50] See: Diamond C. Martha Nussbaum and the need for novels. In: Adamson J., Freadman R., and Parker D. Renegotiating Ethics in Literature, Philosophy, and Theory. Cambridge University Press: Cambridge; 1998. p. 39-64.

[51] Nussbaum M.C. »Finely Aware and Richly Responsible«: Literature and the Moral Imagination. In: Nussbaum M. C. Love's Knowledge. Essays on Philosophy and Literature. Oxford University Press: New York, Oxford; 1992. p. 161-164.

[52] Nussbaum M. C. Not for Profit. Why Democracy Needs the Humanities. Princeton University Press: Princeton and Oxford; 2010. p. 95-120.

[53] Nussbaum M. C. The Discernment of Perception: An Aristotelian Conception of Private and Public Rationality. In: Nussbaum M. C. Love's Knowledge. Essays on Philosophy and Literature. Oxford University Press: New York, Oxford; 1992. p. 97-104.

[54] Nussbaum M.C. Cultivating Humanity: A Classical Defence of Reform in Liberal Education. Harvard University Press: Cambridge; 1997. Nussbaum M. C. Not for Profit. Why Democracy Needs the Humanities. Princeton University Press: Princeton and Oxford; 2010. p. 47-97.

[55] Nussbaum M.C. Upheavals of Thought. The Intelligence of Emotions. Cambridge University Press: New York; 2008. p. 297-454.

[56] Nussbaum M. C. The Discernment of Perception: An Aristotelian Conception of Private and Public Rationality. In: Nussbaum M. C. Love's Knowledge. Essays on Philosophy and Literature. Oxford University Press: New York, Oxford; 1992. p. 97-105.

[57] Brooks T. The Capabilities Approach and Political Liberalism. In: Brooks T., Nussbaum M.C., editors. Rawls's »Political Liberalism«. Columbia University Press: New York; 2015. p. 139-173.

[58] Alexander J. M. Social Justice and Nussbaum's Conception of the Person. In: Comim F., Nussbaum M.C., editors. Capabilities, Gender, Equality. Towards Fundamental Entitlements. Cambridge University Press: Cambridge; 2014. p. 414-436. Okin S.M. Reply. In: Cohen J., Howard M., Nussbaum M. C., editors. Is Multiculturalism Bad for Women? Princeton University Press: Princeton, New Jersey; 1999. p. 115-131.

[59] Okin S.M. Reply. In: Cohen J., Howard M., Nussbaum M. C., editors. Is Multiculturalism Bad for Women? Princeton University Press: Princeton, New Jersey; 1999. p. 129.

[60] Gasper D. Logos, pathos and ethos in Marta C. Nussbaum's capabilities approach to human development, Comim F. Building Capabilities: A New Paradigm for Human Development. In: Comim F., Nussbaum M.C., editors. Capabilities, Gender, Equality. Towards Fundamental Entitlements. Cambridge University Press: Cambridge; 2014. p. $96-130,131-154$.

[61] Vasterling V. Cognitive Theory and Phenomenology in Arendt's and Nussbaum's Work on Narrative. Human Studies. 2007; 30: 79-95.

[62] Eaglestone R. Ethical criticism: Reading after Levinas. Edinburgh University Press: Edinburgh; 1997. p. 45-59. 